\title{
A GROWTH CENTER STRATEGY FOR THE UNITED STATES
}

Niles M. Hansen

University of Texas

This paper proposes a national regional policy based on the development of employment opportunities in intermediate-sized cities, with the condition that a significant number of these opportunities be made available to residents of economically lagging areas. The strategy set forth is based on theee propositions, which will be considered in turn. First, it is not generally feasible to base a national regional strategy on the industrialization of rural areas. Second, it is quite possible that our largest metropolitan areas are too big in terms of both economic efficiency and public preferences, so that their growth should be, if not checked, at least not encouraged. Third, with expanded manpower and human resonrce development programs, and with expanded comprehensive relocation assistance, it is possible to provide alternatives to rural poverty other than the metropolitan ghetto. At the end of the paper the Piedmont Crescent will be considered as the kind of intermediate area upon which a national growth-center strategy could be based.

\section{Attracting Industry to Rural Areas}

Insofar as any coherent regional policy exists in the United States it has been devised and implemented on the assumption that it is feasible to attract sufficient industry to lagging, and for the most part rural, regions of the country to give the people in these regions economic opportunities comparable to those enjoyed by other Americans. Thus, the hot-house industrialization of rural areas has been advocated by, among others, the Department of Agriculture, the Department of Labor, the President"s National Advisory Commission of Rural Poverty, and the writings of some scholars. The author has dwelt at some leggth elsewhere on the appropriateness of these proposals, so only a few summary remarks are given here?

The experience of other countries which have been trying for longer than the United States to promote the growth of large lagging regions indicates biat such efforts have not been generally successful6. Moreover, although there is evidence from the United States and abroad of greater equality in the geogaaphical distribution of manufacturing, this does not imply any concomitant decrease in regional income differences or any relatively greater attractiveness of small towns or rural areas. Recent employment growth has been accounted for primarily by expanding tertiary activities, which have been located primarily in metropolitan areas. Those industries that have tended to leave metropolitan areas have been characterized by relative stagnation or decline; they often seek cheap labor in areas with a redundant agricultural labor force. In contrast, rapidly expanding sectors favor metropolitan areas because of their numerous external economies?

\section{City Size: Economic Efficiency and Public Preferences}

The continuing expansion of large metropolitan agglomerations is by no means necessarily desirable. Questions of efficient city size are difficult to evaluate because of the impossibility of measuring adequately the external economies and diseconomies of metropolitan growth from a social point of view. Moreover, economists have almost completely neglected the issue of personal locational preferences (though they have given considerable attention to time preferences). There are a number of students of metropolitan growth who maintain that there is no evidence that any city is too big, in the sense that marginal costs exceed marginal productivity. ${ }^{8}$ on the other hand, there are those who maintain that some cities have in all probability already become too big. 9 
Such information as we have with respect to people's residential preference patterns indicates that they prefer medium-sized cities. Neutze's findings for Australia show that although firms and families prefer centers with 2,000,000 or more people to small towns, "for many, and quite possibly for most, the advantages of shorter journeys to work, less traffic congestion, and the like make the mediumsized center more attractive."10 By "medium-sized" Neutze means centers with populations of from 200,000 to one million.

French survey data also show that the social costs of urban congestion are considerable and that they are significantly felt by the populations involved. Most Frenchmen would prefer to remain where they presently reside or to live in a locality of more or less similar characteristics. In the Paris agglomeration, however, only a minority of the residents would really prefer to live in the Paris region. Seventy per cent of the Paris residents favor a diminution of the population of the Paris region; similarly, in other areas of heavy urban concentration, such as Flanders, the Artois, and the Lyon region, there is also strong public support for a diminution of their populations. ${ }^{11}$ From these and similar findings, Girard and Bastide conclude that "if the expressed aspirations could be satisfied, the movement away from the countryside, however vigorously condemned, would continue, but a regroupment would be made to the profit of medium and large provincial cities, and Paris would cease to grow. Thus . . . decentralization efforts conform to the wishes of the population."12

Such data as we have for location preferences in the United States show a similar pattern. Data collected by the author from a sample of Mexican-Americans in South Texas indicated that they preferred smaller cities to either large cities, on the one hand, or small towns or rural areas on the other. Similarly, a study of location preferences of graduating seniors in five Eastern Kentucky counties showed that they would prefer living in Louisville or Lexington to either living in a big northern city or remaining in their home counties. 13 In more general terms, a Gallup po11 survey released in May, 1968 showed that 56 per cent of the American people would prefer living in rural areas or in small towns - if jobs were available. In comparison with a poll taken two years earlier, the proportion of persons expressing a preference for city or suburban living dropped by seven percentage points, whereas the proportion preferring a rural location rose by the same amount. 14 No reasons were given for this shift, but presumably increasing tensions of life in large urban centers were a factor. In any case, the number of persons actually moving to rural areas will bear little resemblance to the expressed preferences because the job availability condition will not be satisfied. On the other hand, if life in big metropolitan areas is so unaccommodating, why do they continue to grow? The author has examined this issue at some length in a previous study, and a summary of that discussion will be presented here.15

One of the major conclusions derivable from the assumptions of classical economic theory is that factor mobility will equalize returns to various classes of homogeneous inputs, other things being equal. Space, however, is not homogeneous. Agglomeration of economic activities results in a wide variety of external economies, so that purely market forces tend to concentrate economic activities in a few focal areas. These external economies include relative abundance of public overhead capital, proximity to buyers and sellers, the presence of numerous auxiliary business services (banking, brokerage, insurance), educational facilities, and a well-trained labor force. The attraction of investment to already concentrated areas tends to raise the marginal product of capital in these areas, thereby inducing immigration. Growth of a relatively skilled labor force, induced public overhead investment, and other induced activities further enhance the attractiveness of such areas for private investment. This cumulative process results in ever greater concentration of economic activity and population. However, it also entails numerous social costs, including traffic congestion, inadequate parks and recreation facilities, slum neighborhoods, natural beauty marred by buildings and billboards, and air pollution. Unfortunately, there is nothing in the nature of things to halt this process, because the external diseconomies of congestion often are not internalized by private firms; or if they are internalized, they are not of such a magnitude as to offset the external economies of agglomeration. It is 
this disparity between social and private costs that causes jobs to be created in areas where the net social product is less than it would be in an alternative location (because the wage is higher in congested areas as a result of labor's increased productivity based on privately internalized economies; and because the wage may reflect a payment made to help overcome the external diseconomies borne by the individual). The latter phenomenon is most clearly seen in the supplements paid by oligopolistic firms to professional and managerial personnel to induce them to live in New York City.

It may be argued that individuals will increase their welfare by moving into concentrated areas so long as their marginal private gain in income outweighs their own internalized marginal diseconomies associated with congestion. However, this does not imply an increase in social welfare in a Paretian optimal sense, since such action, by increasing concentration, increases the diseconomies absorbed by previous residents. Some previously inframarginal residents might then prefer to leave the area. This would be the case where income loss from outmigration is less than the increase in marginal disutility resulting from increased congestion. On the other hand, social and economic rigidities, such as habituation to friends and surroundings and the costs of moving, will keep many of these people from moving; they will tend not to minimize their welfare loss unless increased disutility in the agglomeration is substantially greater than the private loss of relocating.

The failure of the free market to halt the growth of large metropolitan areas suggests that public policy measures might be employed to retard their growth and to prevent other cities from expanding to a point where they become overconcentrated. Taxation and credit policy and landuse controls could be used to limit private investment in congested metropolitan areas. However, the more feasible alternative from a political point of view would be to encourage private capital to locate in other areas; public overhead capital could also be used to induce private investment to locate outside of large metropolitan areas. Some of these tools have been used, of course, by our federal agencies concerned with regional development. The problem is that they have been applied for the most part to promote economic growth in rural areas and small towns, and thus they have been not only economically inefficient, but also largely ineffective. To be sure, there may be some sites in rural areas with promising industrial potential, but the most efficient use of public funds might be to encourage the growth of medium-sized cities, especially those which have given some real evidence of growth characteristics. In these places public funds may be integrated with actual or potential external economies to produce rapid growth with a minimum of external diseconomies of congestion. Some may object to this policy on the ground that rapidly-growing places do not need any form of government subsidy. This is quite true in the narrower sense, but if the growth of intermediate-sized centers can be accelerated with government aid by more than growth can be accelerated in lagging regions, and if the accelerated growth of intermediate centers can be made conditional on the granting of newly-created employment opportunities to a significant number of workers from lagging regions (either by means of migration or commuting), then clearly it is economically efficient for the government to attempt to accelerate employment growth in intermediate centers. (In cases where local unemployment rates are relatively high despite high growth rates, 16 policy of growth acceleration would also be made conditional on the employment of the local jobless.) This policy would be in harmony with our limited knowledge of both public locational preferences and efficiency and city sizes.

Brian Berry's work on spatial organization and levels of welfare indicates that labor markets appear to need a minimum population of 250,000 to be viable parts of the urban system. Above this level cities appear to have the conditions necessary for self-sustained growth. On the other hand, few cities with fewer than 50,000 persons seem capable of influencing the welfare of their surrounding regions. On the basis of these findings, Berry draws a number of policy implications. First, the influence of small centers is too limited to justify public investment in them for regional development purposes. Second, an efficient development strategy might concentrate on cities just below the 250,000 population 
leve1. Public investment would provide the push required to get these cities over the threshold to self-generating growth. Third, those persons residing on or between the peripheries of metropolitan labor markets should be given adequate education and training, as we11 as relocation assistance, so that they can find employment in viable labor markets. However, care should be taken to discourage them from locating in big-city ghettos, where employment problems often are as difficult as those in rural areas.17

The 250,000 population threshold is also invoked by Wilbur Thompson, who points out that between 1950 and 1960, only seven out of 212 SMSA's lost population. If one of these, Jersey City, N.J., is regarded as part of the New YorkNortheastern New Jersey SMSA rather than a separate entity, then there were no population declines in SMSA's with over 500,000 people, and only two declines in SMSA's with over 250,000 people (Johnstown and Wilkes-Barre-Hazleton, Pa.). He concludes that "if the growth of an urban area persists long enough to raise the area to some critical size (a quarter of a million population?), structural characteristics, such as industrial diversification, political power, huge fixed investments, a rich local market, and a steady supply of industrial leadership may almost ensure its continued growth and fully ensure against absolute decline--may, in fact, effect irreversible aggregate growth."18

Neutze's investigations employing Australian data indicate that most of the advantages of a city of 500,000 are probably also found in a city of 200,000, but that if a city gets much beyond the half-million level the external diseconomies probably begin to out-weigh the concomitant economies. In any case, he suggests that many firms will maximize their profits in centers with populations between 200,000 and one million. 19 "Let us say," writes Neutze, "that 500,000 was the best size, or at least that most of the firms that could be diverted from $10 c a-$ ting in Sidney would prefer, as an alternative, a city of about 500,000. The objective should be to push the new center as rapidly as possible through the early inefficient stages to get it close to 500,000 and to prevent it from growing past that size. More firms and families will suffer from further growth than will gain." 20 It should be pointed out that Neutze probably underestimates the attractive power of large agglomerations. More firms reap more gains from external economies in big cities than he admits - otherwise, so many of them would not continue to locate in metropolitan areas even after they pass, say, the one million mark. 21 Government planners may try to discourage firms from locating in large agglomerations, but this is different from saying that a firm will be at a disadvantage in locating there. It will not in many cases because it does not internalize many of the diseconomies. Thus, policy measures to induce firms to locate in intermediate areas will have to go beyond simply trying to persuade them that it is to their advantage to shun the large agglomeration.

Finally, if we consider only government services, it is clear that intermediate areas are more efficient than either small towns or large agglomerations. Werner.Hirsch estimates that the greatest economies of scale accrue to a government serving from 50,000 to 100,000 people. His findings are similar to those of the Royal Commission on Local Government in Greater London, which reached the conclusion that the optimum size of a city would be a minimum of about 100,000 people, and a maximum of about $250,000.22$ These results imply that cities that have passed the 250,000 mark may encounter diseconomies of scale in the public sector, but these will probably be outweighed by external economies in the private sector. On the other hand, small towns and rural areas once again are shown to be at a distinct disadvantage.

\section{A Growth Center Policy}

What should be the essential ingredients of a growth center policy designed to take pressure off big cities and to give migrants from lagging rural areas an alternative to the metropolitan ghetto? One approach would be to build entirely new towns. However, there are a number of reasons why this probably would not be satisfactory. Although new towns have received considerable publicity as well as a great deal of support from planners, they have been primarily a physical 
planning device. Too little attention has been given to developing an economic rationale for new towns. British experience has shown that location decisions for new towns have not been made so as to maximize their chances for industrial development, and insufficient attention has been given to developing their employment base. Moreover, most of the literature on new towns demonstrates that they are designed to appeal to people who already live in urban areas and are attached to them. They also seem to be repetitive and monotonous in terms of physical design, and to be generally dull relative to the more animated "downtowns."23

Reston, Virginia, one of the more highly touted experiments with a new town in this country, has proven to be a disappointment. It has had difficulty in attracting residents and it is, in any case, largely a dormitory community rather than an independent center with its own economy, as originally planned. Columbia, another new town near the nation's capital, may meet with greater success, but it is still far from being a center designed to divert migrants from large metropolitan areas. Columbia may prove to be a successful experiment in urban planning, but it is nevertheless part and parcel of the Eastern megalopolis. Indeed, most new town proposals are geared to relocating people within metropolitan areas, and their costs are such that they have little relevance to people in the income groups in which most rural to urban migrants fall.

A more realistic approach to the problem of rechanneling migration streams would be to build on existing external economies in growing cities in the 50,000 to $1,000,000$ population range, and more particularly in growing cities in the 250,000 to 750,000 range. These values are of course not magic numbers but rather rough indicators of the lower and upper limits for intermediate growth centers. As has been shown, there is evidence for believing that self-sustained growth is more assured in a city with 250,000 people than in smaller places. On the other hand, there is increasing danger the increasing external diseconomies will make the marginal social product less than it would be in an alternative city after a city passes the 750,000 mark. However, growing cities that are smaller than 250,000 or larger then 750,000 should not automatically be excluded from consideration.

It has been specified that a growth center policy should build on cities that are already growing relatively rapidly. The simple reason for this is that such places are deomonstrating their ability to create new jobs. There may be cities, and even rural areas, that have not been growing but which for one reason or another may have real job growth potential. Places at or near the intersections of interstate highways may fall into this category. Nevertheless, without preparing a detailed and costly study of every county, village, town and city that claims to have growth potential (in Appalachia alone the states have designated about 125 areas as having significant potential for growth), 24 there is really no practical way to select a system of growth centers other than to rely on the record of the past, particularly the recent past. Sites that may benefit from interstate highway intersections, resource discoveries, or large-scale federal projects need not be automatically exlcuded if they have heretofore been relatively stagnant, but their case should be very strong if they are to be regarded as objects of growth center policy; otherwise, the Pandora's box of Chamber of Commerce salesmen will be opened.

It is not enough that a growth center policy be built upon rapidly-growing cities of intermediate size. Their growth must be related to the employment of persons from lagging regions with high unemployment or low incomes. A rapidly growing, intermediate-sized city located, say, in the Midwestern corn belt may have little relevance to residents of any of our large, lagging rural areas. Workers from Appalachia, the Ozarks, or even the Upper Great Lakes may be unlikely to be persuaded to move to this city, nor would Mexican Americans, Indians, or Negroes. In this event the city would not qualify as a growth center. Such a policy implies that education and training programs in lagging areas be geared to employment opportunities in growth centers. Finally, while in many cases it may be possible for workers in lagging areas to commute to growth centers, often they will have to move, in which case programs of comprehensive relocation assistance 
should be provided. 25 Although growth centers would have to be selected partly on the basis of commuting and migration data, this does not imply reinforcement of existing migration patterns; too often this means movement from rural areas to big-city ghettos. However, migration studies can give insights into the population flows linking lagging rural areas to rapidly growing, intermediate-sized cities, flows which could be reinforced by a growth center policy. The Piedmont Crescent provides an instructive example in this regard.

\section{EDA Development Centers and the Piedmont Crescent}

The Piedmont Crescent includes nine SMSA's: Charlotte, Durham, GreensboroHigh Point, Raleigh, and Winston-Salem, in North Carolina; Greenville, in South Carolina; and Atlanta, Columbus, and Macon, in Georgia. 26 The western portions of these three states are included in the territory of the Appalachian Regional Commission, while the eastern portions are included in the territory of the Coastal Plains Commission.

The states of North Carolina, South Carolina and Georgia have fourteen urban places or sets of places that have been designated by the Economic Development Administration as Economic Development Centers (See Appendix 1). The Public Works and Economic Development Act of 1965 limits such Centers to communities or localized areas with fewer than 250,000 persons where resources hopefully can be used most rapidly and effectively to create more jobs and higher incomes for the populations of their surrounding areas. Although these Centers need not be within depressed areas, they are supposed to promote economic growth and thereby alleviate economic distress in the redevelopment areas of the districts to which the Centers belong.

Despite rapid growth, 27 none of the Piedmont Crescent SMSA's has been designated as a Development Center, although each is either in or bordering on Appalachia or the Coastal Plains. With the exception of Atlanta, two of the Piedmont Crescent SMSA's had 1960 populations of somewhat over 250,000 (Greenville, 255,806; and Charlotte, 316,781). The rest varied between 111,000 and 246,000 . Thus, most of the SMSA's in the Crescent would be able to qualify as Development Centers; with the exception of Atlanta, any of them would be able to qualify with only a relatively small change in the population limitation set by the relevant legislation. Evidence that they are in fact relatively efficient growth centers in the sense of providing jobs for residents of lagging areas - is given in Table 1.

The migration estimates presented in the third row of Table 1 pertain to the polynucleated urban region extending from Raleigh to Greenville. This core area, the Piedmont Industrial Crescent, ${ }^{28}$ is an intermediate urban area in the sense employed earlier in this paper. The total population of the SMSA's in this region is not much above that of the combined EDA Development Centers in the three states under discussion. However, the Industrial Crescent SMSA's are providing substantially more jobs to Appalachian and Coastal Plains residents. In relation to their own population, the Industrial Crescent SMSA's are providing 51.1 jobs per 1000 inhabitants, whereas the comparable value for the Development Centers is only 25.7. If the Georgia SMSA's of Columbus and Macon are included, the SMSA value is still a relatively high 42.0, which is approximately the same as that for Atlanta.

The average income estimates shown in Table 2 indicate that the greatest gains were made by migrants to Atlanta. In this case the increase was 86 per cent, as compated with 69 per cent for the Development Centers and 57 per cent for the other SMSA's, irrespective of whether Columbus and Macon are included. These gains of course reflect increases over time as well as differences attributable to location; however, differences in percentage change values are reflections of locational differences. Excluding Atlanta, it should be noted that the 1965 values (column 10) are not very different for SMSA's and the Development Centers. The higher rate of increase for the migrants to Development Centers is primarily related to their lower incomes in 1960. 
1

Table 1: Estimated Migration from Appalachia and the Coastal Plains to SMSA is it the

Piedmont Crescent and to EDA Economic Development Centers in Georgia,

South Carolina and North Carolina, 1960-65

\begin{tabular}{|c|c|c|c|c|c|c|}
\hline $\begin{array}{l}\text { (1) }{ }^{2} \\
\text { Population } \\
\text { in 1960 } \\
\text { (thousands) }\end{array}$ & $\begin{array}{c}(2) \\
\text { Migrants } \\
\text { from } \\
\text { Appalachia }\end{array}$ & (3) & $\begin{array}{c}(4) \\
\text { Migrants from } \\
\text { Coastal } \\
\text { Plains }\end{array}$ & $(4) \div(1)$ & $(2)+(4)$ & $(6) \div(1)$ \\
\hline
\end{tabular}

\begin{tabular}{|c|c|c|c|c|c|c|c|}
\hline Atlanta & 1,017 & 24,000 & 23.6 & 19,500 & 19.2 & 43,500 & 42.8 \\
\hline Other SMSA's & 1,556 & 35,000 & 22.5 & 30,400 & 19.5 & 65,400 & 42.0 \\
\hline $\begin{array}{l}\text { Other SMSA's, } \\
\text { excluding Columbus } \\
\text { and Macon }\end{array}$ & 1,157 & 32,600 & 28.2 & 26,500 & 22.9 & 59,100 & 51.1 \\
\hline $\begin{array}{l}\text { EDA Development } \\
\text { Centers }\end{array}$ & 1,075 & 10,900 & 10.1 & 18,700 & 17.4 & 29,600 & 27.5 \\
\hline
\end{tabular}

1. These estimates are based on one per cent Social Security sample data.

2. U.S. Bureau of the Census, County and City Data Book, 1967. 
Table 2: Estimated $^{1}$ Average Income Change for Migrants from Appalachia

and the Coastal Plains to SMSA's in the Piedmont Crescent and to

EDA Economic Development Centers in Georgia, South Carolina, and North Carolina, 1960-65

Sending Areas (1960)

\begin{tabular}{|c|c|c|c|c|c|c|c|c|c|c|c|c|}
\hline \multirow[b]{2}{*}{ Receiving Areas (1965) } & \multicolumn{4}{|c|}{ Appalachia } & \multicolumn{4}{|c|}{ Coastal P1ains } & \multicolumn{2}{|c|}{ Appalachia and } & \multirow{2}{*}{$\frac{\text { Coastal }}{(11)}$} & \multirow[b]{2}{*}{$\begin{array}{c}\text { Plains } \\
(12) \\
\text { Percent } \\
\text { Change }\end{array}$} \\
\hline & $\begin{array}{c}(1) \\
1960 \\
\text { Income }\end{array}$ & $\begin{array}{c}(2) \\
1965 \\
\text { Income }\end{array}$ & $\begin{array}{l}\text { (3) } \\
\text { Change }\end{array}$ & $\begin{array}{l}(4) \\
\text { Per cent } \\
\text { Change }\end{array}$ & $\begin{array}{c}5) \\
1960 \\
\text { Income }\end{array}$ & $\begin{array}{l}(6) \\
1965 \\
\text { Income }\end{array}$ & $\begin{array}{l}\text { (7) } \\
\text { Change }\end{array}$ & $\begin{array}{c}(8) \\
\text { Per cent } \\
\text { Change }\end{array}$ & $\begin{array}{c}\text { (9) } \\
1960 \\
\text { Income }\end{array}$ & $\begin{array}{c}(10) \\
1965 \\
\text { Income }\end{array}$ & & \\
\hline Other SMSA's & 2619 & 4114 & 1495 & 57.1 & 2252 & 3549 & 1297 & 57.6 & 2448 & 3851 & 1403 & 57.3 \\
\hline $\begin{array}{l}\text { Other SMSA's } \\
\text { Including Columbus } \\
\text { and Macon }\end{array}$ & 2664 & 4143 & 1479 & 55.5 & 2238 & 3581 & 1343 & 60.0 & 2473 & 3891 & 1418 & 57.3 \\
\hline $\begin{array}{l}\text { EDA Development } \\
\text { Center }\end{array}$ & 2798 & 4512 & 1714 & 61.3 & 2050 & 3585 & 1535 & 74.9 & 2325 & 3926 & 1601 & 68.9 \\
\hline
\end{tabular}

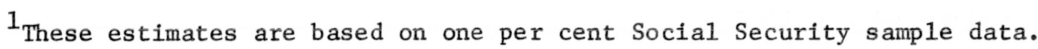


In general, then, an efficient growth center strategy would put greater emphasis on relating problems in the lagging areas under discussion to job opportunities in the Piedment Crescent. While there does not appear to be any income advantage for migrants going from lagging regions to Piedmont Crescent SMSA's relative to those going to EDA Development Centers (unless Atlanta were to be included for policy purposes), there are many more jobs for migrants in the Crescent SMSA's.

\section{Implementing a Growth Center Strategy}

What measures might be undertaken to implement a growth center strategy along lines discussed earlier in this paper? The composition of a development aid tool kit, such as that now used by the Economic Development Administration, should be changed, since the tools will be applied to areas which are already economically healthy and growing, rather than to areas which have relatively poor growth prospects. There should be more emphasis on measures that will appeal to growing industries and less emphasis on subsidies whose principal appeal is to small firms in slow-growing, low-wage industries. There should be more money devoted to equipping relatively sophisticated industrial sites and less to building water and sewer lines (which nay be sorely needed in rural areas, but not a central concern of an agency whose purpose is to inftiate self-sustained growth). The kinds of tools will have to be more varied and flexible than those presently applied in small towns and rural areas. The latter often need so many improvements in order to make them relatively attractive to firms, especially the bigger and more rapidly-growing ones, that whatever a development agency can do within the constraints of its limited resources is not likely to change greatly the total "package" of factors that a firm considers when making a.location decision. This is especially true to the extent that a "worst-first" policy is either explicitly or implicitly followed in granting federal assistance. On the other hand, the growth centers that are being proposed here would have a large variety of external economies. This means in the first place that a given type of aid extended by an economic development agency would not be so visible as it would be in a lagging area. However, if used wisely, it could produce more employment opportunities in the growth center because it could be combined with these external economies. The development agency should seek out the bottlenecks that are hindering or preventing a firm from locating or expanding in the growth center and attempt to provide the assistance needed to overcome the resistance. The situation may call for a certain type of investment in amenities or in more directly productive infrastructure, or for a labor training subsidy, or for some combination of aid devices. Efforts also might be made to enlist the cooperation of prominent business leaders, as is now being done for job creation programs in the ghettos. In any case, it is essential that the aid be made conditional on the extension of job opportunities to persons from lagging regions (and in part to the unemployed and underemployed residents of the center).

The emphasis that is given here to the development of intermediate cities as the principal focus for a national regional policy is based not only on the job growth potential of these cities, but also on the fact that problems related to their growth are still amenable to solution. The massive renewal needs of our large metropolitan areas can still be avoided by careful planning in growth centers. "A city of 'optimal size"" writes Benjamin Higgins, "must be big enough to be urbane in its range of activities and small enough to provide effective proximity to these activities for its residents, with the available techniques of city planning and transportation." 29 Unless the government knows what places are going to grow it can provide public facilities only after the demand has appeared. If there is planned growth of a relatively few centers, then they can be provided with an integrated and coherent system of public facilities in advance of the demand.

Finally, the selective nature of outmigration from lagging areas means that they tend to lose their most vital people - the best workers, the young, the better educated. 30 Moreover, there is evidence that when employment opportunities appear in a lagging area there is a return movement of workers. Since these 
returnees are frequently more highly skilled than the members of the local work force, the hard core unemployed of the area may find little relief for their problems. 31 Thus, outmigration may cause cumulative difficulties in a lagging region, and the benefits from an increase in local employment opportunities may help return migrants more than the local residents. Of course, the positive multiplier effects of any new activity will indirectly benefit the community as a whole, especially if leakages to other areas are minimal.

Whatever may be the consequences of outmigration from lagging areas, it is still clear that policies that merely try to check migration - even by attempting to subsidize the industrialization of rural areas - do little service to either the nation or the individuals concerned, at least from an opportunity cost viewpoint. The remigration problem in particular shows that the real problem of lagging regions is underinvestment in their human resources, rather than migration as such, which is a symptom rather than a cause. Hopefully, a national regional policy would aid areas with problems-occasioned by outmigration to attain new equilibria with a minimum of friction. The nation may also deem it desirable to aid persons in these areas whose prospects for either local employment or for retraining and migration are not bright; older workers in particular would fall into this category. However, it must be recognized that we are talking here about welfare and not about economic development policy. In any case, the main thrust of public policy in lagging regions should still be in the direction of active manpower and human resource programs, including comprehensive job information and relocation assistance.

\section{APPENDIX}

ECONOMIC DEVELOPMENT CENTERS : GEORGIA, SOUTH CAROLINA, AND NORTH CAROLINA

EDA District

Central Savannah River

Coastal

Coastal Plain

Georgia Mountains

Heart of Georgia

\section{Northeast}

Oconee

Slash Pine

Southwest

West Central

Southeastern

Savannah

Pee Dee

Upper Savannah

\section{Number of Counties}

13

6

9

14

9

9

7

9

13

8

10

4

6

6
Economic Development Centers

Augusta-Swainsboro, Ga. Brunswick-Hinesville, Ga. Valdosta-Tifton, Ga. Gainesville-Toccoa, Ga. Dublin, Ga.

Athens, Ga. Milledgeville, Ga. Waycross, Ga. Albany-Bainbridge, Ga. Americus, Ga.

Wilmington-Fayetteville, N.C. Aiken, S. C. Florence-Darlington, S.C. Greenwood, S.C.

NOTE: This list includes all relevant Centers designated through March, 1969. 
* The research summarized in this paper was made possible by the financial support of the Office of Economic Research of the Economic Development Administration, Department of Commerce, under Project 非OER-227-G-68-11. Additional support was received from the Manpower Administration, Department of Labor, under Project 非1-19-68-17. The findings do not necessarily reflect the viewpoints of either agency. The author also would like to acknowledge the assistance of David Hirschberg and Dann Milne in data preparation.

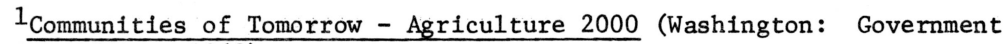
Printing Office, 1968).

2 Manpower Report of the President, 1968 (Washington: Government Printing office, 1968), pp. 128-139.

3he People Left Behind (Washington: Government Printing Office, 1967).

${ }^{4}$ See, for example, William H. Nicholls, Southern Tradition and Regional Progress (Chapel Hill: University of North Carolina Press, 1960), pp. 13-14; Dale E. Hathaway and Brian E. Perkins, "Occupational Mobility and Migration From Agriculture," in Rural Poverty in the United States (Washington: Government Printing office, 1968), pp. 185-237.

${ }^{5}$ See, for example, "Regional Development and the Rural Poor," Journal of Human Resources, forthcoming; "Unbalanced Growth and Regional Development," Western Economic Journal 4, No. 1 (Fall 1965): 3-14; and French Regional Planning (Bloomington: Indiana University Press, 1968).

6Hansen, "Regional Development and the Rural Poor," op. cit.

${ }^{7}$ Victor Fuchs, The Growing Importance of the Service Industries (New York: National Bureau of Economic Research Occasional Paper No. 96, 1965); Changes in the Location of Manufacturing in the United States Since 1929 (New Haven: Yale University Press, 1962); and Erling 01sen, "Erhvervs1ivets Lokalisering," Nationalфkonomisk Tidsskrift, Nos. 1-2 (1965): 18-30.

${ }^{8}$ See, for example, William Alonso, "Urban and Regional Imbalances in Economic Development," Economic Development and Cultural Change 17, No. 1 (October 1968): 1-14; Hans Blumenfeld, "The Modern Metropolls," in Cities (New York: Alfred Knopf, 1965), pp. 48-49.

${ }^{9}$ Edgar M. Hoover, "The Evolving Form and Organization of the Metropolis," in Harvey S. Perloff and Lowden Wingo, Jr., Issues in Urban Economics (Baltimore: The Johns Hopkins Press, 1968), p. 268; and "Some 01d and New Issues in Regional Development," University of Pittsburgh Center for Regional Economic Studies Occasional Paper No. 5, 1967, p. 6. See also, Kevin Lynch, "The City as Environment," in Cities, op. cit., pp. 192-201; Kingsley Davis, "The Urbanization of Human Population," Ibid., p. 23; and Rene Dubos, "Promises and Hazards of Man's Adaptability," in Henry Jarrett, ed., Environmental Quality in a Growing Economy (Baltimore: The Johns Hopkins Press, 1966), pp. 27-29, 38.

$10_{G}$. M. Neutze, Economic Policy and the Size of Cities (New York: Augustus Ke1ley, 1967), pp. 109-110.

11 Hansen, French Regional Planning, op. cit., pp. 34-37.

12 Alain Girard and Henri Bastide, "Les problèmes démographiques devant 1'opinion," Population 15 (April-May 1960), 287. 
13 These finding are reported inddetail in a forthcoming report prepared for the Department of Labor. See also Robert L. Wilson, "Livability of the City: Attitudes and Urban Development," in F. Stuart Chapin, Jr., and Shirley F. Weiss, ed., Urban Growth Dynamics (New York: John Wiley and Sons, 1962), pp. 359-399; and John Gulick, Charles E. Bowerman, and Kurt W. Back, "Newcomer Enculturation in the City: Atttudes and Participation," ibid., pp. 356-357.

${ }^{14}$ Cited in a speech by Secretary of Agriculture Orville Freeman before the conference on Rural-Oriented Industry, Washington, D. C., 13 May 1968.

${ }^{15}$ See Hansen, French Regional Planning, op. c1t., Chapter 1.

${ }^{16}$ High growth rates are by no means necessarily associated with low unemployment ates. See George Iden, "Unemployment Classification of Major Labor Areas, 1950-1965," Journal of Human Resources 2, No. 3 (Summer 1967): 391; and Gene Laber, "Unemployment Classification of Major Labor Areas, 1950-1965: A Comment," Journal of Human Resources 3, N0. 4 (Fal1 1968): 515-519.

17Brian J. L. Berry, "A Summary - Spatial Organization and Levels of Welfare: Degree of Metropolitan Labor Market Participation as a Variable in Economic Development," Research Review (EDA) (July 1968), pp. 1-6.

18 Wilbur R. Thompson, A Preface to Urban Economics (Baltimore: The Johns Hopkins Press, 1965), p. 24 .

${ }^{19}$ Neutze, 으. cit., pp. 103, 109-118.

${ }^{20}$ Ibid., pp. 117-118.

21 Between 1962 and 1967 there was about a 16 percent increase in employment in the fifteen largest SMSA;s for employees covered in County Business Patterns. See Bureau of the Census, County Business Patterns, 1962, U. S. Summary (Washington: Government Printing Office, 1963), pp. 164-166; and County Business Patterns, 1967, U. S. Summary (Washington: Government Printing Office, 1968), pp. 231-233.

22Werner 2. Hirsch, "The Supply of Urban Public Services," in Perloff and Wingo, op. cit., pp. 509-511.

23Jonathan Lindley, "The Economic Environment and Urban Development," a paper presented to the Eight Annual Conference, Center for Economic Projections, National Planning Association, 28 April.1967, p. 17..

${ }^{24}$ Ralph R. Widner, "The First Three Years of the Appalachian Program: An Evaluation," Appalachia 1, No. 11 (August 1968): 19.

25The feastbility and efficiency of such programs have been demonstrated. See Audrey Freedman, "Labor Mobility Projects for the Unemployed," Monthly Labor Review 91, No. 6 (June 1968): 57-62; "Moving to Work," Washington: Labor Mobility Services Unit, U.S. Employment Service, 1968; Garth L. Mangum, "Moving Workers to Jobs," Poverty and Human Resources Abstracts 3 (November-December 1968) : $12-18$.

${ }^{26}$ C. E. Bishop and F. A. Mangum, "The Crescent's Human Resources," in James G. Maddox, ed., Growth Prospects of the Pledmont Crescent (Raleigh, N.C.: Agricultural Policy Institute, North Carolina State University, 1968), p. 15. 


\author{
FOOTNOTES---Continued
}

27 Between 1950 and 1960, the population of the United States increased by 18 percent, while that in SMSA's grew by 27 percent. With the exception of Durham (10.2 percent), all of the Piedmont Crescent SMSA's grew faster than the overall national rate, and all but three grew. faster than the rate for all SMSA's. U.S. Bureau of the Census, City and County Data Book, 1967 (Washington: Government Printing Office, 1967). The Bureau of the Census estimates that the population of the United States grew by 8.1 percent from 1960 to 1965, and that in SMSA's by 9.1 percent. During the same period the Piedmont Crescent SMSA's had the following estimated rates of growth: Atlanta 19.6, Columbus 19.3, Raleigh 15.4, Charlotte 14.7, Macon 11.7, Durham 9.8, Winston ASalem 9.5, Greensboro-High Point 8.1, and Greenville 3.8. U.S. Bureau of the Census, Current Population Reports, Series P-25, No. 415, "Projections of the Population of Metropolitan Areas: 1975," (Washington: Government Printing Office, 1969), pp. 15-18.

${ }^{28}$ F. Stuart Chapin, Jr., "Introduction," in F. Stuart Chapin, Jr. and Shirley F. Weiss, eds., op. cit., pp. 1-21.

${ }^{29}$ Benjamin Higgins, Economic Development, revised edition (New York: W. W. Norton, 1968), p. 468 .

30 John Lansing and Eva Mueller, The Geographic Mobility of Labor (Ann Arbor: University of Michigan Survey Research Center, 1967); Hathaway and Perkins, 으. cit.

${ }^{31}$ John B. Parr, "Outmigration and the Depressed Area Problem," Land Economics 42, No. 2 (May 1966): 149-159. 